\title{
Heavy metals accumulation in plants growing in ex tin mining catchment
}

\author{
${ }^{1 *}$ M. A. Ashraf; ${ }^{1}$ M. J. Maah; ${ }^{2}$ I. Yusoff \\ ${ }^{1}$ Department of Chemistry, University of Malaya, Kuala Lumpur 50603, Malaysia \\ ${ }^{2}$ Department of Geology, University of Malaya, Kuala Lumpur 50603, Malaysia \\ Received 6 June 2010; $\quad$ revised 6 December 2010; accepted 2 February 2011; available online 1 March 2011
}

\begin{abstract}
ABSTRAC T: The degree of contamination by heavy metals (arsenic, copper, lead, tin and zinc) in soil and transfer to plants has been studied. Specimens of plant species from five locations in an area of $10 \times 10 \mathrm{~m}$ were sampled with their corresponding soils. Thirty six plant species including two shallow water aquatic plants were identified. Soil and plant specimens were analyzed by using inductively coupled plasma optical emission spectrometry. It was found that metal concentration in soil was highly variable while concentration of metals in plants directly depends on the concentration of metals it was rooted. Roots showed highest metal concentration followed by leaves, shoots and flowers. Bioconcentraion factor and translocation factor were calculated, representing Cyperus rotundus L. as a potential tin-hyperaccumulator plant, previously not reported in literature. Plant Species Imperata cylindrica, Lycopodium cernuum, Melastoma malabathricum, Mimosa pudica Linn, Nelumbo nucifera, Phragmites australis L., Pteris vittata L. and Salvinia molesta, were metal accumulator while Acacia podalyriaefolia G. Don, Bulb Vanisium, Dillenia reticulate King, Eugenia reinwardtiana, Evodia roxburghiania Hk. f. clarke, Gleichenia linearis, Grewia erythrocarpa Ridl., Manihot esculenta Crantz, Paspalum conjugatum Berguis, Passiflora suberosa, Saccharum officinarum, Stenochlaena palustris (Burm.) Bedd. and Vitis trifolia Linn. were tolerated plant species. All other studied plants were excluders. Identified plant species could be useful for revegetation and erosion control in metals contaminated ex-mining sites. Morphological changes such as reduction in size, change in color and deshaping have also been observed in plant species with high metal values.
\end{abstract}

Keywords: Cyperus rotundus L.; Hyperaccumulator; Hyper tolerant; Leaves; Remediation; Root; Shoot

\section{INTRODUCTION}

Metal mining is the second large source of heavy metal contamination in soil after sewage sludge (Nouri, 1980; Singh et al., 2005). Mining activities are well known for their deleterious effects on the environment, due to the deposition of large volumes of wastes on the soil. (Dudka and Adriano, 1997; Goyal et al., 2008; Nouri et al., 2009) affirmed that the negative impact of these mining activities on the surroundings is mainly due to the presence of high volumes of tailings (Nouri et al., 2011). These tailings usually have unfavourable conditions to natural vegetation growing on it, such as low pH (Wong et al., 1998), toxic metal concentrations (Norland and Veith, 1995; Wong et al., 1998; Malakootian et al., 2009; Zvinowanda et al., 2009) low water retention capacity (Henriques and

凶*Corresponding Author Email: chemaqeel@gmail.com Tel./ Fax: +6017 2770972
Fernandes, 1991; Norland and Veith, 1995) and low levels of plant nutrients (Wong, 2003). In most cases, tailings present on steep slopes, are unstable and prone to erosion (Henriques and Fernandes, 1991). All these factors contribute to pollution for the soil, ground and surface waters.

Specifically metals are non-degradable and therefore can persist for long periods in aquatic as well as terrestrial environments (Nouri et al., 2008). These metals may be transported through soils to reach groundwater or may be taken up by plants, including agricultural crops (Atafar et al., 2010). Generally, mine tailings are a major source of contaminants, mainly of heavy metals in water (Younger, 2001), soil (Alvarez et al., 2003; Nwuche and Ugoji, 2008) and biota (Brotheridge et al., 1998; Mateo et al., 2006; Wilson and Pyatt, 2007), which have been studied extensively 
by many researchers, such as (Dudka and Adriano, 1997; Johansen and Asmund, 2001; Johnson and Hallberg, 2005). The availability of metals in soil is a naturally selection phenomenon for plants, that are capable of surviving or reproducing under high metal concentrations (Bradshaw et al., 1978). Some plant species can grow in these severe conditions. Excessive concentration of heavy metals in plants can cause oxidative stress and stomatal resistance (Fayiga et al., 2004; Shah et al., 2009). It can also affect photosynthesis and chlorophyll florescence processes (Monni et al., 2001). Copper can inhibit photosynthesis and reproductive processes; lead reduces chlorophyll production; arsenic interferes with metabolic processes, while zinc and tin stimulate the growth of leaves and shoots; ultimately plant growth becomes limited or impossible (Gardea-Torresdey et al., 2005; Ling et al., 2009; Ayari et al., 2010).

Plants can tolerate high heavy metals concentration from soil by two basic strategies (Baker, 1981). The first strategy is called accumulation strategy where metal can accumulate in plants at both high and low concentration from soil (McGrath et al., 2001). These plants are capable of rendering the metals in various ways, for instance by binding them to cell walls, compartmentalizing them in vacuoles or complexing them to certain organic acids or proteins (Reeves and Baker, 2000). The second strategy is called exclusion strategy, where transport of heavy metals in shoots and leaves is limited over a wide range of metal concentrations in soil. Some of the plants make stable metal complexes in the root cells to prevent metal translocation from the roots to above-ground tissues.

Methods such as covering the mine tailings with non-polluted materials or changing their locations can reduce the environmental risks. However, such methods are expensive and often impractical due to the large areas and volumes of these tailings. In situ stabilization by chemical amendments is not favoured because of their unproven durability as well as the need for regular inspections. The other major limitation of these techniques is that they fail to enhance the unsightly nature of abandoned mine sites (Tordoff et al., 2000). The use of plants can be an alternative means of decreasing the environmental risk posed by mine tailings. Plants can be used to stabilize the surface, thus reducing erosion. This option is called phytostabilization and considers the use of metaltolerant plant species to immobilize heavy metals through absorption and accumulation by roots, adsorption onto roots or precipitation within the rhizosphere (Wong, 2003). These processes also decrease metal mobility and also reduce the likelihood of metals entering into the food chain. Therefore, the use of metal-tolerant native flora represents an inexpensive long-term solution.

Metalliferous soils, which are heavily enriched with toxic metals, support the growth of specific plant species called Metallophytes that grow on mineralized areas and can develop mechanisms that allow them to resist metal concentrations which are toxic to most plants (Boularbah et al., 2000; Reeves and Baker, 2000 ). Metallophytes have long been attracted the interest of botanists and are now considered as potential tools for phytoremediation (phytostabilization or phytoextraction). Some metallophytes are called hyperaccumulator, as these plants can accumulate very high metal concentrations in their aerial tissues, besides normal levels found in most species (Baker and Brooks, 1989). There are also some plant species called excluders that can restrict uptake and transport of elements between roots and shoots, maintaining low metal levels inside plant body over a wide range of external concentrations (Baker, 1981). More than 400 hypertolerant species have been identified (Brooks, 2000), most of them associated with metal rich soils. Some of these hypertolerant plants also have the ability to accumulate high concentrations of metals in their tissues. These accumulators or hyperaccumulators plants can be used to decontaminate soils by "phytoextraction" (Freitas et al., 2004; Yanqun et al., 2004; Sun et al., 2005). Approximately 450 plants species have been classified as hyperaccumulators of heavy metals, most of hyperaccumulators (about 300) can hyperaccumulate Ni (Baker, 1981; Baker et al., 1994; Morel et al., 1997). To classify a given plant as a hyperaccumulator, the concentration criterion depends on the type of metal. For example, a plant is defined as a Ni hyperaccumulator if the $\mathrm{Ni}$ concentration in leaves exceed $1000 \mathrm{mg} / \mathrm{kg}$ dry weight DW, whereas for a Zn hyperaccumulator, the leaf concentration should exceed $10000 \mathrm{mg} / \mathrm{kg}$ DW (Baker, 1995).

This research aimed to investigate polluted soils that surrounds mining slag piles. The investigation will help to identify the endemic excluder, accumulator and hyperaccumulator plant species or ecotypes and to evaluate their capability to remove heavy metals from the soil. This information could be useful to establish 
guidelines for the selection of adapted plant species that can be used for phytoremediation of mining sites with low $\mathrm{pH}$, high salinity and high metal tolerances.

This study was carried out in the former tin mining catchment Bestari Jaya (Batang Berjuntai old name), starting from January 2010 till July 2010 which include field and laboratory work. Bestari Jaya is located at $3^{\circ}$, 24' $40.41^{\prime \prime} \mathrm{N}$ and $101^{\circ} 24^{\prime} 56.23^{\prime \prime} \mathrm{E}$, and is a part of district Selangor in Selangor state that includes three towns Mukim Batang Berjuntai, Mukim Ulu Tinggi and Mukim Tanjung Karang (Fig. 1). Selangor is the second largest tin producer state (22 \%) after Perak (63\%) in Malaysia. Bestari Jaya was one of the most important tin mining sites in Selangor state and is now sand mining site. Bestari Jaya has a tropical, humid climate, with very little variations in temperature throughout the year. The average temperature of the area is $32^{\circ} \mathrm{C}$ during day and $23^{\circ} \mathrm{C}$ at night. An annual average rainfall of $2000 \mathrm{~mm}$ and $3000 \mathrm{~mm}$ with potential evaporation of $1600 \mathrm{~mm}$ per year (Ashraf et al., 2010).

The area consists of myriad ecosystems which can be subdivided into several categories such as degraded land, large open lakes and small ponds, earth drains and wetlands area, tin tailings (sand and slime tailings), logged peat swamp forest land in east. The contribution of storm water, peat swamp forest water and recent sand mining activity has caused severe environmental pollution due to drainage problem in the area. The wetlands have an area of 579.7 hectors stretched along the north western border of the site. Several useful plant species have been identified in the wetland while several harmful weed species have been also identified in the study area that cause blocking of water courses and water become foul due to large masses of water leaves.

The whole area is sandy in texture and is representative of entire examining area in the country. The parent soil material is of reverine alluvium, with the $\mathrm{pH}$ range of 3.5 to 5.5 .

\section{MATERIALS AND METHODS}

\section{Sampling}

The field work was conducted by the writer with a team of two research assistants during the months of February and March 2010. Seven sampling sites were established (S1-S7). S1 and S2 were located at downstream of catchment along sides of river Ayer Hitam, S3 in the reclaimed ex-mining area, S4, S5, S6 on mine dumps and S7 at a mineral processing tailing pond (Fig. 2). These areas were selected based on topography, vegetation, and slope. In order to determine the abundance of each plant species in soils, seven $10 \times 10$ m plots were constructed. Plant samples (leaves, shoots, roots and flowers) were collected from every plant rooted in the sampling location. About one hundred roots, shoots, leaves

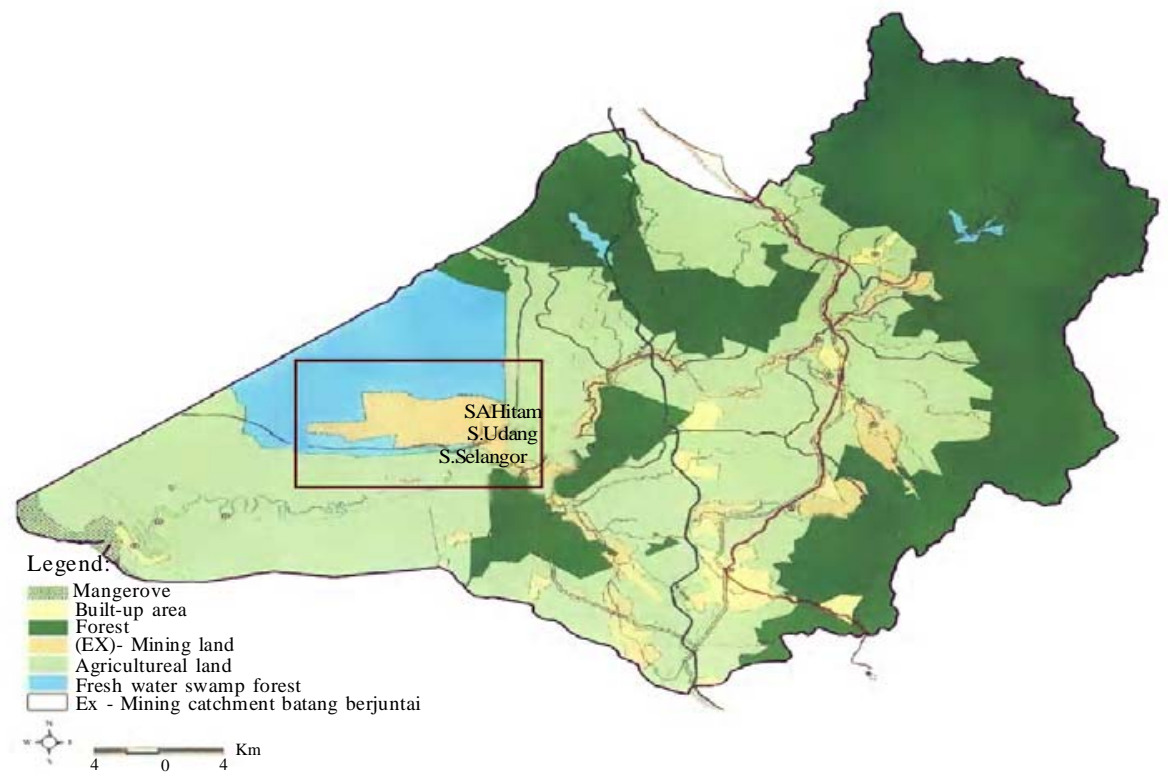

Fig. 1: District Kuala Selangor showing study area 
and flowers were collected from each specie of plant. The samples were collected from all sides of the plant using shoppers and pruning shears. The samples of roots, leaves and shoots were selected from each plant specie in a way that they were of similar age and colour that it would not be too unreasonable to compare the metal values in the nets of similar organs. Five replicates of each plant were collected and two of them were employed for the purpose of identification by dichotomous keys (Mickel, 1992; Moran and Riba, 1995). The rest of the replicates were mixed to obtain a composite sample, which was then utilized to quantify the metals concentration. The nomenclature of the plant species is according to International code of botanical nomenclature (Mcneill, 2006). The leaves and flowers were preserved in 5-5-5 FAA solution (formic acid $5 \%$, acetic acid $5 \%$, methyl alcohol $5 \%$ and distilled water $85 \%$ by volume), whilst the roots and shoots were preserved in 13-13-13 FAA solution (formic acid $13 \%$, acetic acid $13 \%$, methyl alcohol $13 \%$ and distilled water $61 \%$ by volume) the rest of plant samples were each labelled with a numbered tag and were then pressed between sheets of paper in order to preserve them for laboratory analysis. Soil samples were also collected at the same time and same place where the plants were sampled. Five surface samples $(0-40 \mathrm{~cm})$ of soil one from the centre and the rest from each vertex were taken to obtain a composite sample corresponding to each plant or group of plants growing in the same place. Sampling location S7 includes a shallow pond area thus sediment core samples were collected along with corresponding plant species.

\section{Soil analysis}

Analytical grade reagents were used throughout the experiment. Distilled-deionized water was prepared by passing distilled water through a Milli-Q reagent grade water system. Glassware and polyethylene containers were soaked overnight in $10 \%(\mathrm{v} / \mathrm{v})$ laboratory reagent grade nitric acid, rinsed three times with distilled water, then three times with distilleddeionized water before use. The composite samples of soil and sediment were air-dried and milled so as to pass through a $2 \mathrm{~mm}$ sieve, homogenized and stored in plastic bags prior to laboratory analysis. The $\mathrm{pH}$ was measured in a $1: 2.5$ soil $/ \mathrm{H}_{2} \mathrm{O}$ suspension (Thomas, 1996) using a waterproof $\mathrm{pH} / \mathrm{ORP}$ meter. Cation Exchange Capacity (CEC) was measured following the

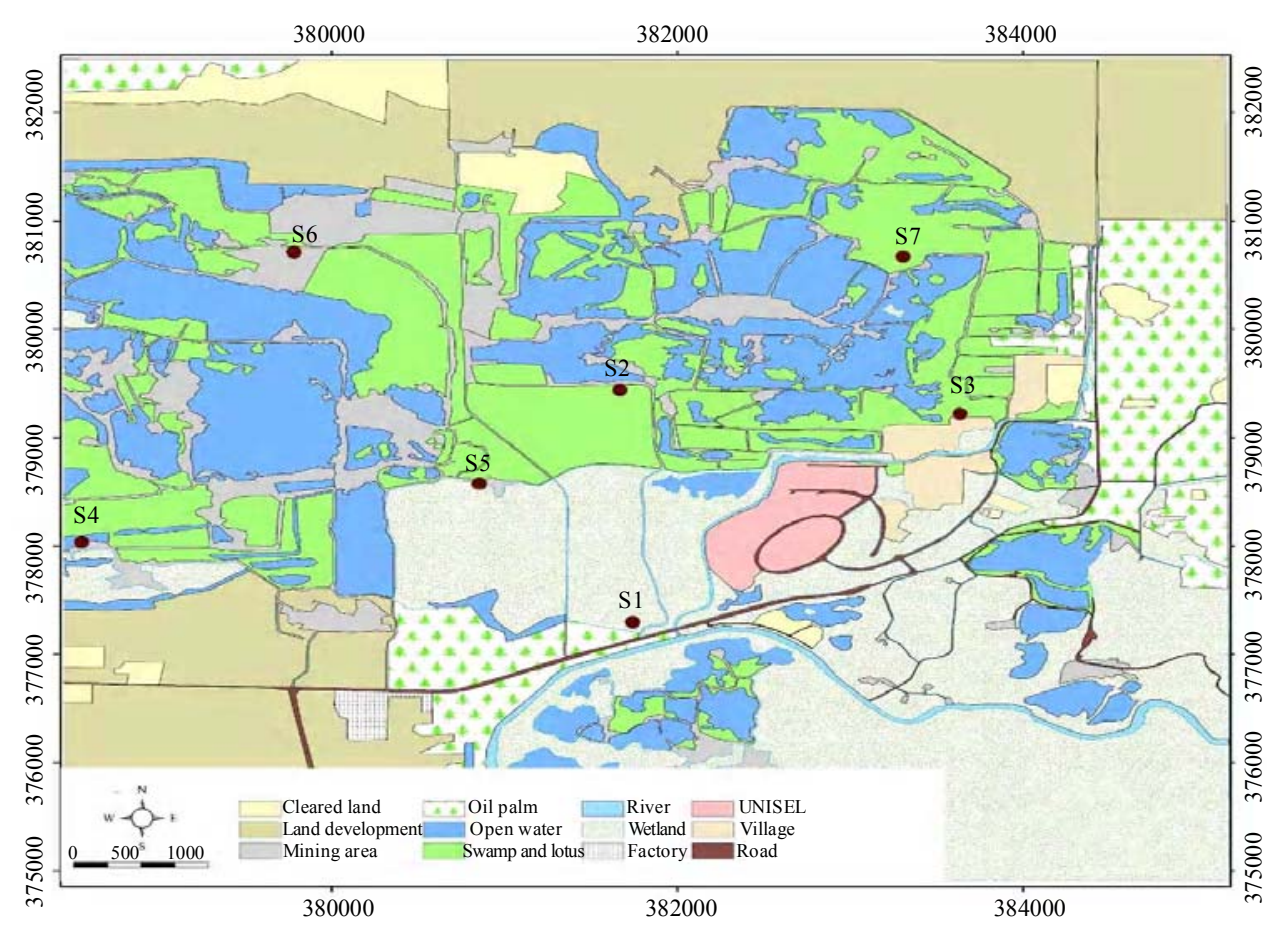

Fig. 2: Sampling locations in the study area (Schematic diagram) 
standard procedure (Rowell, 1994) and the texture was analyzed by the hydrometer method as described by (Gee and Bauder 1986). Organic matter was determined by the Walkley and Black procedure (Nelson and Sommers, 1982). All parameters were determined in triplicate. For the analysis of metals homogenised soil samples were ashed in a muffle furnace at $400^{\circ} \mathrm{C}$ for $1 \mathrm{~h}$ and were digested by microwave assisted acid digestion (Camel, 2000). Solutions from digested soil samples were stored in $100 \mathrm{~mL}$ high density polyethylene samples bottles at $4^{\circ} \mathrm{C}$ until analysis. Total metals in soil were measured in a sub-sample of $0.5 \mathrm{~g}$ soil inductively coupled plasma optical emission spectrometry ICP-OES (Varian) (Perkin Elmer AAAnalyst). Working standards for chemical analyses were prepared from Perkin-Elmer stock solutions. The methodology for total metal concentration in soil was referenced using the CRM027-050 Certified Material (Resource Technology Corporation, USA) for soil and was analyzed concurrently with the soil samples. Recovery of metal was $99 \%$ for tin, $97 \%$ for arsenic, $112 \%$ for copper, 99 $\%$ for zinc and $94 \%$ for lead and the coefficient of variation was between $3 \%$ and $7 \%$ when analyzed in triplicate.

\section{Plant analysis}

Plants samples were cleaned sequentially with a phosphate-free detergent (Extran $2 \%$ ), rinsed once with tap water, once with distilled water and finally twice with deionized water to remove adhering materials. Absorbing (roots) and non-absorbing parts of plants (leaves, shoots, flowers etc.) were usually separated in order to obtain information about the species' ability to transfer metals. Plant samples were divided into three portions, first for wet chemical destruction (Keller et al., 1998; Scholes et al., 1999; Batty et al., 2000), second for dry ash chemical destruction (Baudo et al., 1985; Hall and Pulliam, 1995; Peverly et al., 1995; Ye et al., 1997), in third portion only leaves of plants were used for wet chemical extraction to obtain amino acids and proteins present in the plant leaves (Gibbs, 1951; Charles and Glenn, 1953; Carpena-Ruiz et al., 1989). The proteins present were then further hydrolysed in order to obtain the amino acids units. Solutions from digested plant samples obtained from wet and dry ash chemical destruction were stored in $100 \mathrm{~mL}$ high density polyethylene samples bottles at $4{ }^{\circ} \mathrm{C}$ until analysis. Solution concentrations were measured using inductively coupled plasma optical emission spectrometry ICP-OES (Varian) (Perkin Elmer AA
Analyst). Working standards for chemical analyses were prepared from Perkin-Elmer stock solutions. The methodology for total metal concentration in plants were referenced using CRM 281 (Griepink and Muntau, 1988) for plants and was analyzed concurrently with the plant samples. Recoveries of metals by dry ash chemical destruction method of analysis were $99 \%$ for tin, $91 \%$ for arsenic, $95 \%$ for copper, $90 \%$ for zinc and $93 \%$ for lead and the coefficient of variation was between $8 \%$ and $14 \%$ when analyzed in triplicate. The results obtained by wet chemical destruction method of digestion have limited metal concentration values so not discussed here.

In third portion, the amino acids obtained from plant leaf extract were purified and identified by ascending paper chromatographic method (Mizell et al., 1961). All chromatographic work was carried out in an air conditioned room at $20{ }^{\circ} \mathrm{C}$. Chromatograms of all fractions were run in conjunction with known standards and were examined under ultraviolet light, both before and after the development.

\section{Determination of translocation factor (tf) and bioconcentration factor (bcf)}

To analyze the total metal concentration in dry weight (DW) taken by the upper parts of the plants from ground level, a term was used called TF which is defined as (Deng et al., 2004; Santillan et al., 2010): $\mathrm{TF}=$ Metal in above-ground DW/ Metal in root DW Bioconcentration factor BCF, represents the ratio of metal concentration DW in the plant to the metal concentration DW in the soil. BCF is an indication of the magnification of contaminants from a lower to a higher trophic level. For plants, the BCF has been used as a measure of the metal accumulation efficiency, whereby value greater than 1 is an indication of plants potential to phytoextract (Zhang et al., 2002; Santillan et al., 2010). BCF is expressed as (Dowdy and McKone, 1997; Santillan et al., 2010):

$\mathrm{BCF}=$ Metal in Whole plant DW/Metal in soil DW

\section{RESULTS AND DISCUSSION}

\section{Characterization of soil}

Table 1 shows mean values of the characteristics of top- soil samples from ex-tin mining area, Bestari Jaya. $\mathrm{pH}$ values ranged from acidic to neutral (4.8-7.2).

The $\mathrm{pH}$ was acidic in the location (S4-S6), while it was slightly acidic at (S1-S3) and was neutral at (S7). The carbonate percentages were in a broad range and 
the organic matter values were less than $10 \%$. According to (SISS, 1985) criteria, the soil of the location (S4-S6) mine dumps can be considered poor in organic matter. The cationic exchange capacity (CEC) represents the ability of the soils to absorb or release cations and consequently is an important parameter in sites contaminated by heavy metals. Organic matter and clay minerals are responsible for the CEC. CEC ranged from low 17.81 to high 26.98 $\mathrm{cmol} / \mathrm{kg}$. According to (Conesa et al., 2006) $\mathrm{pH}$ and ECs are the most important factors because under acidic conditions the tailings matrix will dissolve more salts (Wong et al., 1998). These both parameters are the key in determining plant colonization of land that is degraded by mining activity. Due to the moderately acidic and saline conditions of the soil, $\mathrm{pH}$ and ECs could be the limiting factors for plant establishment in the studied zone. At all sampling locations, the soil showed a sandy texture. Sandy substrates generally present oxidizing conditions however, in this case, the water-saturation state of soils and the flooding of sediments explained the reducing environment.

In the study area analyzed metal contents in soils were highly variable and also found to be high (Table 3 ) depending on the mine and type of ore (Boularbah et al., 2006). At sampling location (S1-S3) in the reclaimed and river side, metals concentration were averaged from 13 to 89,11 to 47,18 to 71,8 to 91,123 to $271 \mathrm{mg} / \mathrm{kg} \mathrm{DW}$ for lead, copper, zinc, arsenic and tin respectively while sampling location (S4-S7) in the mine dumps and the tailing ponds showed mean values of 541 to 3589,761 to 2781,638 to 3698,239 to 2956, 1896 to $6453 \mathrm{mg} / \mathrm{kg}$ DW for lead, copper, zinc, arsenic and tin respectively. However, only the high metal contents in soil are discussed here due to brevity.

\section{Identification and classification of plants}

Thirty six plant species were identified in the study area (Table 2) that belong to different plant families such as Blechnaceae (1), Casuarinaceae (1), Compositae (1), Cucurbitaceae (1), Cyperaceae (1), Dilleniaceae (2), Euphorbiaceae (4), Fabaceae (3), Gleicheniaceae (1), Gramineae (1), Lycopodiaceae (1), Malvaceae (1), Melastomataceae (1), Mimosaceae (1), Myrtaceae (1), Nelumbonaceae (1), Nepenthaceae (1), Orchidaceae (1), Passifloraceae (1), Poaceae (3), Pteridaceae (1), Rutaceae (1), Salviniaceae (1), Schizaeaceae (1), Tiliaceae (1), Ulmaceae (1), Verbenaceae (1) and Vitaceae (1) largely as a result of the sampling criteria. Some of the identified species, such as Acacia podalyriaefolia G. Don, Antidesma ghaesembilla Gaertn., Evodia roxburghiana Hk. f., Imperata cylinderica, Lygodium mycrophyllum (Cav.) R. Br., Melastoma malabathricum L., Phragmites australis L., Stenochlaena palustris(Burm.) Bedd., were sampled from three or more locations in the study area (Table 2).

Plant species were categorized according to their TF values into four groups (Table 2). First group contain hyperaccumulator plants with TF values above ten (Table 2 and 3). Only Cyperus rotundus L. follow the criteria for hyperaccumulator. Total $1990.44 \mathrm{mg} / \mathrm{kg}$ of metal concentration was found in roots, shoots, leaves and flowers which show that this plant has a potential to hyperaccumulate tin metal, previously not reported in literature. Second group contains hpertolerant plants with TF values above one but below ten (Table 2 and 3). Results in (Table 2 and 3 ) indicate that these plants adopted an accumulation strategy with regard to different studied metals. Eight plant species were identified as dominant hypertolerant

Table 1: Chemical and physical characteristics of soil

\begin{tabular}{cccccccccc}
\hline Location & Sand \% & Silt \% & Clay \% & Textural Class & $\mathrm{pH}$ & $\mathrm{ECs}\left(\mathrm{dSm}^{-1}\right)^{\mathrm{b}}$ & $\mathrm{CaCO}_{3}$ & $\mathrm{OM}^{\mathrm{c}} \%$ & $\begin{array}{c}\mathrm{CEC} \\
(\mathrm{cmol}(+) / \mathrm{kg})^{\mathrm{d}}\end{array}$ \\
\hline S1 & $60 \pm 14^{\mathrm{a}}$ & $29 \pm 9$ & $11 \pm 3$ & Sandy & $6.1 \pm 0.02$ & $18 \pm 8$ & $5.7 \pm 0.8$ & $8.39 \pm 0.7$ & $17.81 \pm 4$ \\
S2 & $65 \pm 13$ & $26 \pm 8$ & $9 \pm 4$ & Sandy & $6.3 \pm 0.01$ & $17 \pm 7$ & $18.4 \pm 0.6$ & $9.91 \pm 0.4$ & $19.43 \pm 3$ \\
S3 & $67 \pm 11$ & $21 \pm 9$ & $12 \pm 3$ & Sandy & $6.7 \pm 0.01$ & $11 \pm 5$ & $6.9 \pm 1.2$ & $7.98 \pm 0.5$ & $13.76 \pm 3$ \\
S4 & $59 \pm 13$ & $30 \pm 7$ & $11 \pm 2$ & Sandy & $5.1 \pm 0.01$ & $12 \pm 4$ & $12.1 \pm 2.4$ & $5.13 \pm 0.3$ & $26.98 \pm 3$ \\
S5 & $68 \pm 13$ & $20 \pm 8$ & $12 \pm 3$ & Sandy & $4.9 \pm 0.01$ & $10 \pm 5$ & $2.5 \pm 0.9$ & $4.78 \pm 0.4$ & $24.42 \pm 3$ \\
S6 & $61 \pm 12$ & $27 \pm 8$ & $12 \pm 4$ & Sandy & $4.8 \pm 0.01$ & $14 \pm 4$ & $0.99 \pm 0.3$ & $5.18 \pm 0.3$ & $23.77 \pm 4$ \\
S7 & $61 \pm 14$ & $29 \pm 9$ & $10 \pm 2$ & Sandy & $7.2 \pm 0.02$ & $10 \pm 6$ & $1.4 \pm 0.8$ & $7.24 \pm 0.5$ & $18.53 \pm 4$ \\
\hline
\end{tabular}

${ }^{\mathrm{a}} \pm \mathrm{SD}, \mathrm{n}=5 ; \quad{ }^{\mathrm{b}}$ Electrolytic conductivity; ${ }^{\mathrm{c}}$ Organic matter; ${ }^{\mathrm{d}}$ Cation exchange capacity 
species that includes Imperata cylindrica, Lycopodium cernuum, Melastoma malabathricum, Mimosa pudica Linn, Nelumbo nucifera, Phragmites australis L., Pteris vittata L. and Salvinia molesta (Table2). Third group contains tolerant plants with TF values less then one. These include Acacia podalyriaefolia G. Don, Bulb Vanisium, Dillenia reticulate King, Eugenia reinwardtiana, Evodia roxburghiania Hk. f. Clarke, Gleichenia linearis, Grewia erythrocarpa Ridl., Manihot esculenta Crantz, Paspalum conjugatum Berguis, Passiflora suberosa, Saccharum officinarum, Stenochlaena palustris(Burm.) Bedd. and Vitis trifolia
Linn. (Table 2). These results supported the suggestion that plants have adopted an exclusion strategy. This strategy allows them to form metal stable complexes in their root cells, which results in a limited metal translocation to above-ground parts. The fourth group, categorized as excluders, as these plants can grow in heavy-metal polluted soils without accumulating significant quantities (Baker, 1981). These include Casuarina equisetifolia Forest, Eupatorium odoratum L, Momordica balsamina L., Tetracera indica Merr., Antidesma ghaesembilla Gaertn., Bridelia monoica (Lour.) Merr., Mallotus paniculatus

Table 2: Complete List of plant species with status growing on ex-mining region; Bestari Jaya, Peninsular Malaysia

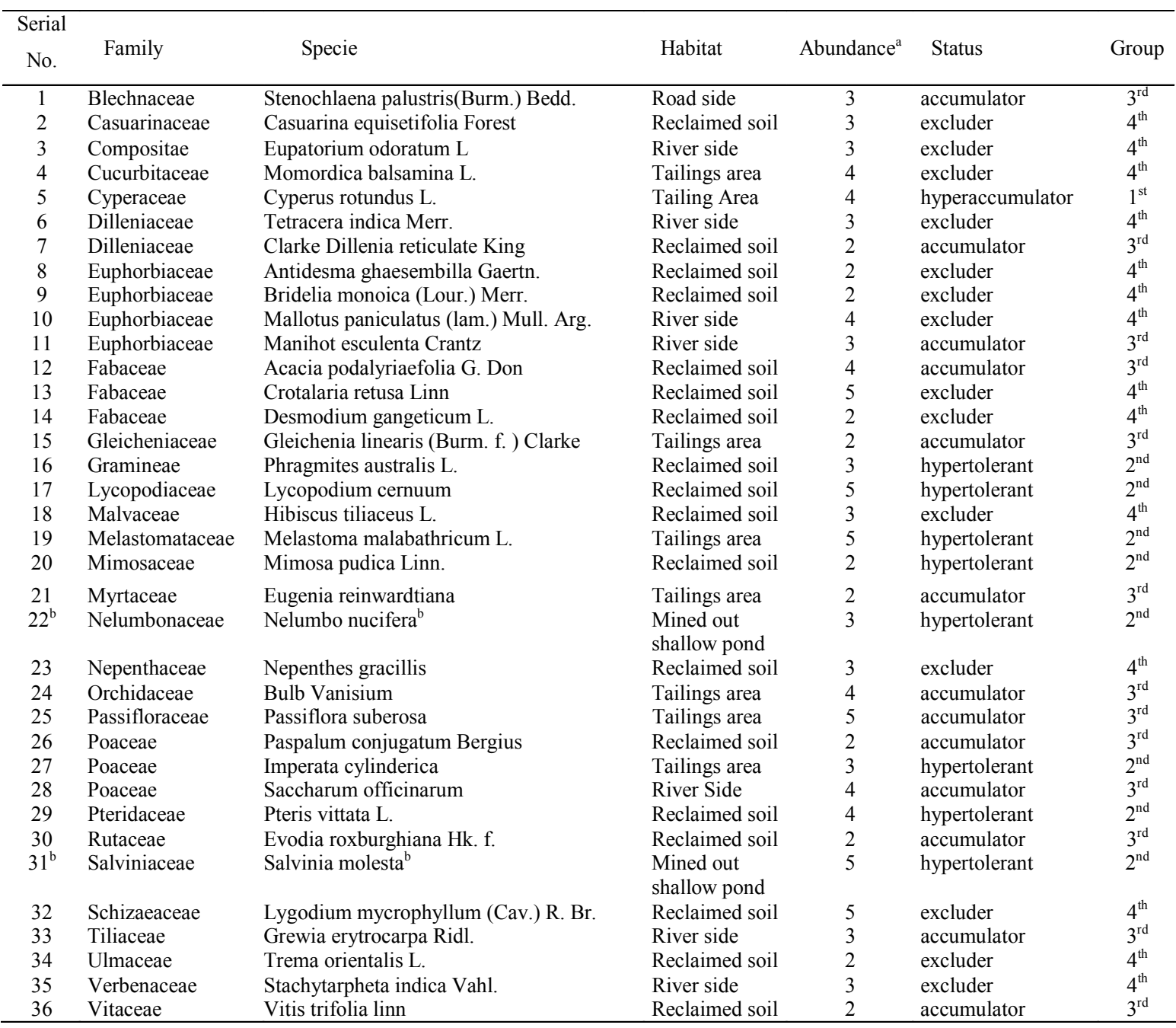

a Abundance class: 1 , very rare; 2 , rare; 3 , occasional; 4 , frequent; 5 , abundant

${ }^{\mathrm{b}}$ specie is an aquatic specie found in shallow mined out pond in the sampling location S7 
(lam.) Mull. Arg ,Crotalaria retusa Linn, Desmodium gangeticum L., Hibiscus tiliaceus L., Nepenthes gracillis, Lygodium mycrophyllum (Cav.) R. Br., Trema orientalis L. and Stachytarpheta indica Vahl. These plant species have TF values $<0.1$. Possibly these plants use mechanism that avoids excessive uptake of metals and metal is absorbed and translocated only in non- toxic quantities. These plants are not useful for phytoextraction in substrates with physicochemical conditions similar to those found in Bestari Jaya soils, since plants employed in phytoextraction treatments must accumulate more than $1000 \mathrm{mg} / \mathrm{kg}$ DW, should exhibit values of TF and BCF larger than unity, and should produce high quantities of biomass (Min et al.,

Table 3: Heavy metals concentration in dominant species in ex-mining region; Bestari Jaya, Peninsular Malaysia

\begin{tabular}{|c|c|c|c|c|c|c|c|}
\hline \multicolumn{8}{|c|}{$\mathrm{mg} / \mathrm{kg} \mathrm{DW}{ }^{\mathrm{a}}$} \\
\hline$\overline{\text { Plant }}$ & Roots & Shoots & Leaves & Flowers & Soil/ substrate & $\mathrm{BCF}^{\mathrm{C}}$ & $\mathrm{TF}^{\mathrm{d}}$ \\
\hline & & & LEAD & & & & \\
\hline Cyperus rotundus L. & 440.13 & 151.19 & 188.76 & 142.16 & 2561.80 & 0.3599 & 1.094 \\
\hline Imperata cylindrica & 152.79 & 260.00 & 345.75 & 291.33 & 1973.46 & 0.5319 & 5.867 \\
\hline Lycopodium cernuum & 688.90 & 24.51 & 56.20 & 13.40 & 3589.00 & 0.2181 & 0.136 \\
\hline Melastoma malabathricum L. & 491.57 & 104.33 & 178.22 & 151.16 & 3589.00 & 0.2578 & 0.881 \\
\hline Mimosa pudica Linn. & 641.00 & 25.16 & 63.10 & 35.19 & 1000.81 & 0.7638 & 0.191 \\
\hline Nelumbo nucifera & 518.10 & 71.35 & 109.60 & 85.75 & 2588.40 & 0.3031 & 0.514 \\
\hline Phragmites australis L. & 745.13 & 56.74 & 129.00 & 110.68 & 1459.73 & 0.7135 & 0.396 \\
\hline Pteris vittata $L$. & 114.56 & 278.23 & 412.50 & 0.00 & 1231.22 & 0.6540 & 6.023 \\
\hline Salvinia molesta & 162.72 & 244.10 & 367.19 & 0.00 & 2588.40 & 0.2990 & 3.754 \\
\hline \multicolumn{8}{|c|}{ COPPER } \\
\hline Cyperus rotundus $L$. & 689.12 & 78.46 & 134.10 & 85.76 & 1756.00 & 0.5623 & 0.432 \\
\hline Imperata cylindrica & 128.13 & 241.51 & 267.96 & 175.50 & 2689.40 & 0.3023 & 5.343 \\
\hline Lycopodium cernuum & 724.13 & 18.91 & 24.10 & 21.10 & 2561.14 & 0.3077 & 0.088 \\
\hline Melastoma malabathricum L. & 498.67 & 45.91 & 88.24 & 51.10 & 2561.14 & 0.2670 & 0.370 \\
\hline Mimosa pudica Linn. & 689.34 & 78.12 & 102.31 & 71.23 & 1355.60 & 0.6941 & 0.364 \\
\hline Nelumbo Nucifera & 128.40 & 245.98 & 326.53 & 144.98 & 2561.46 & 0.3302 & 5.585 \\
\hline Phragmites australis L. & 633.46 & 345.91 & 426.78 & 352.39 & 1119.71 & 0.7158 & 1.773 \\
\hline Pteris vittata $L$. & 548.13 & 78.23 & 156.96 & $\mathrm{~b}$ & 998.22 & 1.5705 & 0.427 \\
\hline Salvinia molesta & 680.91 & 104.35 & 91.40 & b & 2561.46 & 0.3422 & 0.286 \\
\hline \multicolumn{8}{|c|}{ ZINC } \\
\hline Cyperus rotundus L. & 624.39 & 157.21 & 213.55 & 111.63 & 1524.89 & 0.7258 & 0.771 \\
\hline Imperata cylindrica & 214.71 & 245.24 & 288.56 & 198.12 & 2891.72 & 0.3273 & 3.407 \\
\hline Lycopodium cernuum & 598.22 & 110.38 & 186.72 & 56.91 & 2891.72 & 0.3292 & 0.591 \\
\hline Melastoma malabathricum L. & 678.58 & 86.15 & 103.24 & 81.10 & 1624.15 & 0.5843 & 0.397 \\
\hline Mimosa pudica Linn. & 810.12 & 38.94 & 63.14 & 54.12 & 2887.56 & 0.3346 & 0.192 \\
\hline Nelumbo Nucifera & 751.88 & 22.33 & 78.78 & 42.10 & 3671.50 & 0.2437 & 0.190 \\
\hline Phragmites australis $L$. & 356.90 & 211.40 & 228.34 & 140.30 & 2569.00 & 0.3647 & 1.624 \\
\hline Pteris vittata $L$. & 744.13 & 45.10 & 88.35 & b & 1578.71 & 0.5558 & 0.178 \\
\hline Salvinia molesta & 128.31 & 136.40 & 222.56 & b & 3671.50 & 0.1327 & 2.796 \\
\hline \multicolumn{8}{|c|}{ ARSENIC } \\
\hline Cyperus rotundus $L$. & 711.98 & 94.13 & 88.50 & 34.90 & 2477.40 & 0.3751 & 0.305 \\
\hline Imperata cylindrica & 458.20 & 88.94 & 103.85 & 102.30 & 2477.40 & 0.3040 & 0.643 \\
\hline Lycopodium cernuum & 376.44 & 118.24 & 210.57 & 86.41 & 2567.70 & 0.3083 & 1.102 \\
\hline Melastoma malabathricum L. & 791.52 & 12.78 & 56.10 & 10.14 & 2328.18 & 0.3739 & 0.099 \\
\hline Mimosa pudica Linn. & 791.86 & 56.22 & 62.46 & 34.12 & 2388.14 & 0.3955 & 0.192 \\
\hline Nelumbo Nucifera & 561.18 & 288.47 & 315.00 & 326.06 & 2878.00 & 0.5179 & 1.655 \\
\hline Phragmites australis L. & 746.63 & 34.55 & 51.88 & 34.52 & 2231.85 & 0.3887 & 0.161 \\
\hline Pteris vittata $L$. & 288.93 & 312.78 & 398.00 & $\mathrm{~b}$ & 2231.85 & 0.4479 & 2.458 \\
\hline Salvinia molesta & 628.72 & 110.36 & 128.50 & $\mathrm{~b}$ & 2878.00 & 0.3014 & 0.379 \\
\hline \multicolumn{8}{|c|}{ TIN } \\
\hline Cyperus rotundus $L$. & 194.80 & 658.12 & 670.44 & 661.88 & 5432.57 & 0.4022 & 10.215 \\
\hline Imperata cylindrica & 412.45 & 344.12 & 428.10 & 177.42 & 5624.12 & 0.2421 & 2.301 \\
\hline Lycopodium cernuum & 677.11 & 129.52 & 111.76 & 81.98 & 5832.41 & 0.1715 & 0.477 \\
\hline Melastoma malabathricum L. & 486.92 & 296.31 & 362.12 & 374.95 & 5200.63 & 0.2923 & 2.121 \\
\hline Mimosa pudica Linn. & 756.28 & 325.10 & 241.27 & 98.32 & 5832.41 & 0.2436 & 0.878 \\
\hline Nelumbo Nucifera & 581.10 & 128.44 & 172.68 & 142.12 & 5478.21 & 0.1869 & 0.762 \\
\hline Phragmites australis L. & 738.46 & 109.56 & 126.11 & 74.33 & 5586.47 & 0.1876 & 0.419 \\
\hline Pteris vittata $L$. & 755.23 & 397.62 & 468.91 & $\mathrm{~b}$ & 5757.65 & 0.2816 & 1.146 \\
\hline Salvinia molesta & 817.55 & 224.31 & 298.24 & b & 5478.21 & 0.2446 & 0.638 \\
\hline
\end{tabular}

${ }^{a}$ Dry Weight \pm SD, $n=5$ b Plant without this organ

${ }^{\mathrm{c}}$ Bio Concentration Factor ( Ratio of metals in above-ground biomass and roots to soil)

${ }^{\mathrm{d}}$ Translocation Factor (Ratio of metals in above-ground biomass to roots) 
2007; Reeves and Baker, 2000; Dowdy and McKone, 1997).

Results of most dominant plant species are discussed here while others were omitted due to brevity. Lead occurred at the highest concentrations (Table 3; Fig. $3 a)$ in five species exactly in Cyperus rotundus $L$, Imperata cylinderica, Lycopodium cernuum, Phragmites australis L. and Salvinia molesta where we obtained values around $897.08 \mathrm{mg} / \mathrm{kg}$ lead in Imperata cylinderica. The lowest values were recorded in Lycopodium cernuum with around $94.11 \mathrm{mg} / \mathrm{kg}$ lead.

[A] Concentration of lead in some dominant plant species

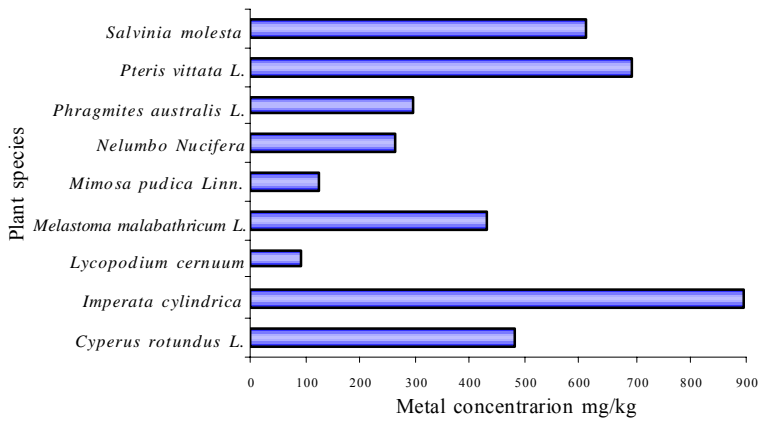

[C] Concentration of zinc in some dominant plant species

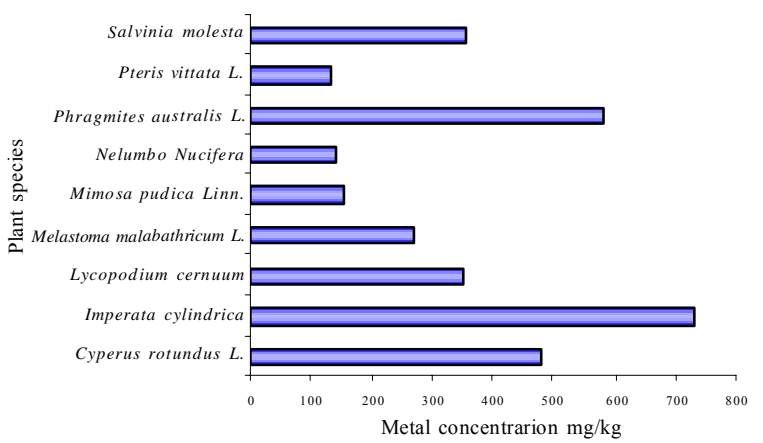

Similarly, Copper concentration have found (Table 3; Fig. 3b), significantly higher in three plant species, namely Imperata cylinderica, Phragmites australis $L$ and Nelumbo nucifera, with $684.97 \mathrm{mg} / \mathrm{kg}, 717.49 \mathrm{mg} /$ $\mathrm{kg}$ and $1125.08 \mathrm{mg} / \mathrm{kg}$, respectively. The lowest values of copper were obtained for Cyperus rotundus $L$, Lycopodium cernuum, Melastoma malabathricum L., Mimosa pudica Linn., Pteris vittata L. and Salvinia molesta with less than $64.11 \mathrm{mg} / \mathrm{kg}$ copper in Lycopodium cernuum. Highest concentration of zinc $731.92 \mathrm{mg} / \mathrm{kg}$ was found in Imperata cylinderica (Table
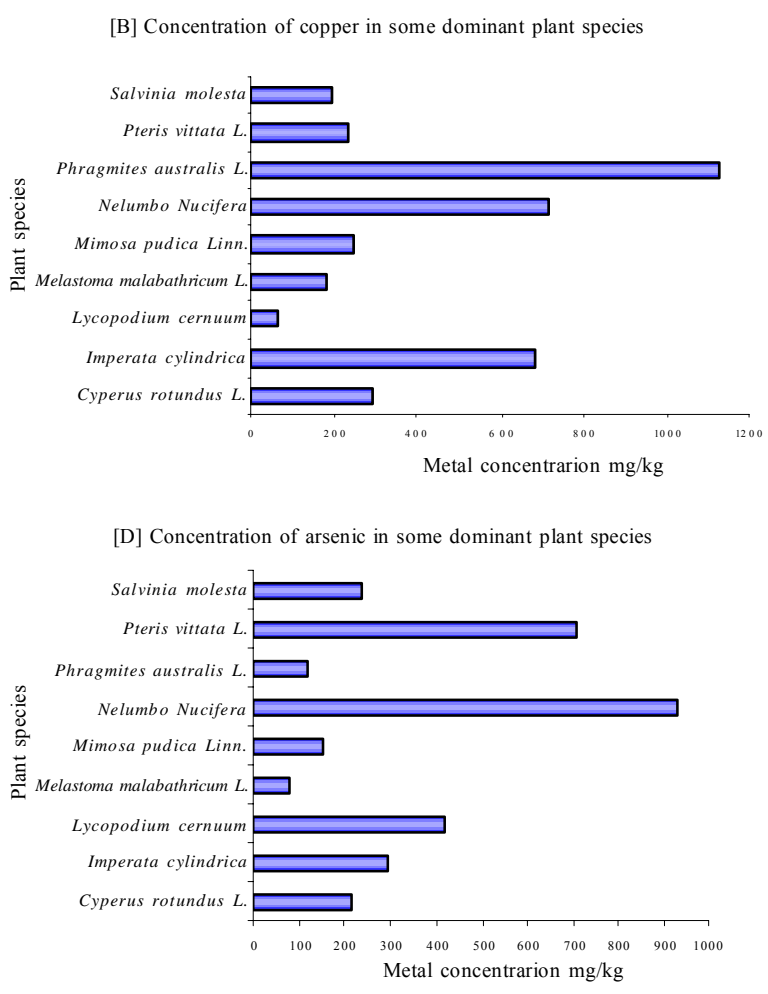

[E] Concentration of tin in some dominant plant species

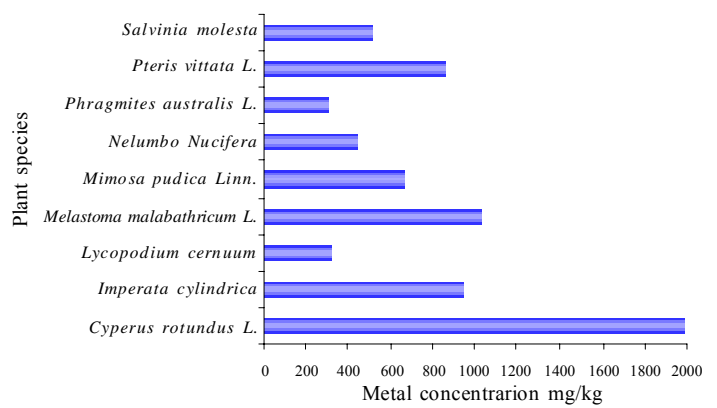

Fig. 3: Dominant plant species with heavy metals concentration in ex-mining region; Bestari Jaya, Peninsular Malaysia 
3; Fig. 3c) whereas lowest concentration $133.45 \mathrm{mg} / \mathrm{kg}$ was found in Pteris vittata L. Arsenic occurred high in Pteris vittata L. and Nelumbo Nucifera where it was $929.53 \mathrm{mg} / \mathrm{kg}$ in Nelumbo Nucifera (Table 3; Fig. 3d) while lowest $79.02 \mathrm{mg} / \mathrm{kg}$ was in Melastoma malabathricum L.Tin concentration was found significantly higher in four plant species namely Cyperus rotundus L, Imperata cylinderica, Melastoma malabathricum $L$. and Pteris vittata $L$. The highest concentration of tin $1990.44 \mathrm{mg} / \mathrm{kg}$ was found in Cyperus rotundus $L$ (Fig. 4) with a potential of being hyperaccumulator plant (Table 3; Fig. 3e) while the lowest $310.00 \mathrm{mg} / \mathrm{kg}$ was found in Phragmites australis $L$.

Bioconcentration factor BF values (Mattina et al., 2003 ) in all studied plants were from 0.2181 to 0.7638 for lead, 0.2670 to 1.5705 for copper, 0.1327 to 0.7258 for zinc, 0.3014 to 0.5179 for arsenic and 0.1715 to 0.4022 for tin (Table 3). These high values indicate that plant species are suitable for phytoextraction and follow the criteria of hypertolerants while fourth group plants have values in range (0.0091-0.067) which show that these plants can be suited to soil stabilization because there is less risk of metals entering the food chain if the plants are consumed.

On the other hand, it is difficult to find plants with the entire characteristic to follow the criteria of hyperaccumulation. The results thus confirmed the complexity of a phytoextraction process, due to the availability of metal varying spatially in the zone and affecting the capacity of a plant to accumulate it. Cyperus rotundus $L$. identified in this study have not been previously reported as hyperaccumulator plant by other researchers. Thus, the present research can

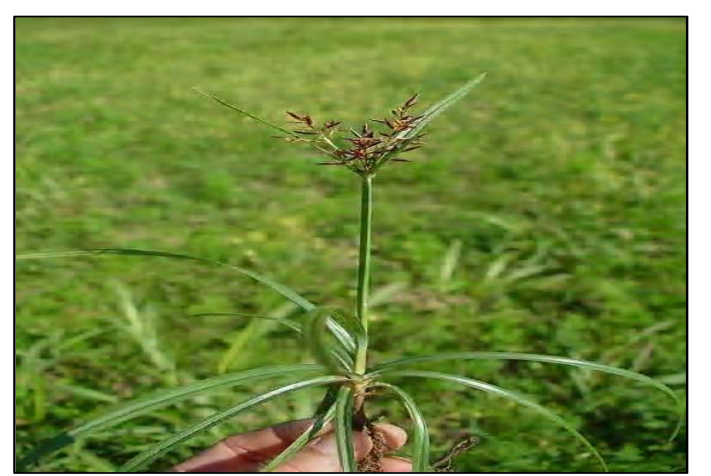

Fig. 4: Cyperus rotundus $L$. as a potential tin-hyper accumulator plant contribute to increase the list of species with such capacities.

\section{Analysis of amino acids}

The purpose of this work was to observe any changes in the formation of amino acids due to accumulation of heavy metals and their ultimate effect on plant morphology. Amino acids separated from plants are shown in (Table 4 and 5). Plants with extremely high or low metal values in their tissues did not follow the normal processes of metabolic activities. For normal metabolism plant requires a certain optimal concentration of metals present in their tissues. Excess or deficiency of metals, disorganises some of the normal processes of plant metabolism whilst some others have no marked effects (Prasad and Strzalka, 2002). The unbalanced concentrations of the metals were revealed by either the absence or presence of certain amino acids in the plants.

Presence or absence of certain types of amino acids in plants suggests that the synthesis of amino acids is in one way or another affected by the levels of concentration of metals in the plants. Table 4 shows that certain plants with relatively high concentrations of heavy metals lack certain type of amino acids such as aspartic acid $\left(\mathrm{C}_{4} \mathrm{H}_{7} \mathrm{NO}_{4}\right)$, arginine $\left(\mathrm{C}_{6} \mathrm{H}_{14} \mathrm{~N}_{4} \mathrm{O}_{2}\right)$, alanine $\left(\mathrm{C}_{3} \mathrm{H}_{7} \mathrm{NO}_{2}\right)$, glutammic acid $\left(\mathrm{C}_{5} \mathrm{H}_{9} \mathrm{NO}_{4}\right)$, glycine $\left(\mathrm{C}_{5} \mathrm{H}_{5} \mathrm{NO}_{2}\right)$, and serine $\left(\mathrm{C}_{3} \mathrm{H}_{7} \mathrm{NO}_{3}\right)$. The high concentration of metals has hindered the activities of some of the enzymes or reactants, particularly in the synthesis of the amino acids (Bischof, 1996). In addition, those plants are also lacking some of the amino acids and invariably exhibit suppressing morphologies. Thus, high concentration of metals causes failure to synthesize of some amino acids, resulting unhealthy growth in plants. Plants with relatively low to moderate concentrations of metals in their tissues, synthesize most of the amino acids and do not show modified morphologies (Table 4). The synthesis of amino acids depends largely on the processes and products of photosynthesis and respiration occurring in the plants. The glutamic acid $\left(\mathrm{C}_{5} \mathrm{H}_{9} \mathrm{NO}_{4}\right)$ is formed as a result of direct amination of $\alpha$-ketogluteric acid $\left(\mathrm{C}_{5} \mathrm{H}_{6} \mathrm{O}_{5}\right)$ and is one of the primary products of photosynthesis and respiration. The possible reaction is as follows:

$\alpha-\mathrm{KG}+\mathrm{NH}_{3}+\mathrm{NAD}^{+}$(reduced) $/ \mathrm{PO}_{3}^{-4} \leftrightarrow$

$\mathrm{C}_{5} \mathrm{H}_{9} \mathrm{NO}_{4}+\mathrm{H}_{2} \mathrm{O}+\mathrm{NAD}^{+} / \mathrm{PO}_{3}^{-4}$ 
When the mechanism for photosynthesis and respiration are impaired such as the high concentrations of metals, $\alpha$-ketogluteric acid $\left(\mathrm{C}_{5} \mathrm{H}_{6} \mathrm{O}_{5}\right)$ would not be available or present in insufficient quantity for the synthesis of glutamic acid $\left(\mathrm{C}_{5} \mathrm{H}_{9} \mathrm{NO}_{4}\right)$. In addition, the dinucleotide also rendered inactive by the high concentration of metals. The formation of other amino acids which are formed through enzymatic chainreactions of the glutamic acid $\left(\mathrm{C}_{5} \mathrm{H}_{9} \mathrm{NO}_{4}\right)$ also would not occur since the latter is not available.

The amino acids are the aspartic acid $\left(\mathrm{C}_{4} \mathrm{H}_{7} \mathrm{NO}_{4}\right)$, the arginine $\left(\mathrm{C}_{6} \mathrm{H}_{14} \mathrm{~N}_{4} \mathrm{O}_{2}\right)$ and the alanine $\left(\mathrm{C}_{3} \mathrm{H}_{7} \mathrm{NO}_{2}\right)$. Their formation from the glutamic acid is as follows:

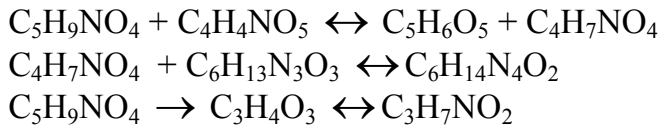

Similarly, the synthesis of the other amino acids also depends on the processes and products of respiration and photosynthesis. Serine $\left(\mathrm{C}_{3} \mathrm{H}_{7} \mathrm{NO}_{3}\right)$, alanine $\left(\mathrm{C}_{3} \mathrm{H}_{7} \mathrm{NO}_{2}\right)$ and glycine $\left(\mathrm{C}_{5} \mathrm{H}_{5} \mathrm{NO}_{2}\right)$ were formed from 3phosphoglyceric acid $\left(\mathrm{C}_{3} \mathrm{H}_{7} \mathrm{O}_{7} \mathrm{P}\right)$ which is one of the products of respiration and photosynthesis. The probable reactions are as follows:

$3 \mathrm{PG} \leftrightarrow 2 \mathrm{PG} \leftrightarrow \mathrm{C}_{3} \mathrm{H}_{7} \mathrm{NO}_{3}$ $3 \mathrm{PG} \leftrightarrow \mathrm{C}_{3} \mathrm{H}_{5} \mathrm{O}_{6} \mathrm{P}_{1} \leftrightarrow \mathrm{C}_{3} \mathrm{H}_{7} \mathrm{NO}_{2}$ $\mathrm{C}_{3} \mathrm{H}_{7} \mathrm{NO}_{3}+\mathrm{C}_{19} \mathrm{H}_{23} \mathrm{~N}_{7} \mathrm{O}_{6} \leftrightarrow$ OH-Me- $\mathrm{H}_{4} \mathrm{~F}+\mathrm{C}_{5} \mathrm{H}_{5} \mathrm{NO}_{2}$

The formation of the above amino acids depends on the availability of the 3-phosphoglyceric acid as well as on the various enzymes which participate in the reactions.

One plant, Vitis trifolia Linn. has cystine $\left(\mathrm{C}_{6} \mathrm{H}_{12} \mathrm{~N}_{2} \mathrm{O}_{4} \mathrm{~S}_{2}\right)$, which is the amino acid with a sulphur radical in its structure. Cystine $\left(\mathrm{C}_{6} \mathrm{H}_{12} \mathrm{~N}_{2} \mathrm{O}_{4} \mathrm{~S}_{2}\right)$ was not detected in other studied plants. The presence of cystine suggests that the Vitis trifolia Linn. grows on soil that is enriched with sulphur or sulphates. One of the possible reaction by which the sulphur is incorporated into an amino acid to form cystine is as follows:

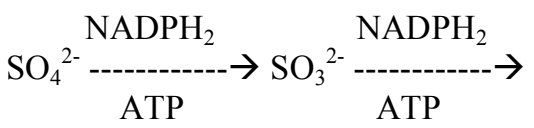

$$
\begin{aligned}
& \mathrm{H}_{2} \mathrm{~S}+\mathrm{C}_{3} \mathrm{H}_{7} \mathrm{NO}_{3}---\rightarrow \mathrm{C}_{6} \mathrm{H}_{12} \mathrm{~N}_{2} \mathrm{O}_{4} \mathrm{~S}_{2}+\mathrm{H}_{2} \mathrm{O}
\end{aligned}
$$

Since the amino acids have simple units which are joined together by peptide bonds to form various types of proteins, it can be expected that some of the proteins would be absent when their primary amino acids were not formed.

The determination of type of amino acids in plants suggests that the synthesis of amino acids is in a way affected by the concentration of metals in the plants which have high concentrations of the metals. However the analysis does not really indicate which metals and the level of concentration that hinder the synthesis of amino acids. A detailed study using controlled experiments, precised methods of separating and identifying amino acids and isotope experiments may assist to establish the effects of each heavy metal and levels of concentration of that metal on the synthesis of each type of the amino acid.

\section{Effect of concentration of metals on plant morphologies}

Metals are commonly and usually freely accepted and accumulated by plants upto a certain level of concentrations. An excess of particular metal above the critical level of accumulation may impair the health of plant or may even kill it (Sheldon and Menzies, 2005). That metal would have a toxic effect on the normal metabolism of the plant. Plants growing on soils with higher metal value, exhibit characteristics of unhealthy growth (Rout and Das, 2003). The morphology of these plants differs to some extent from those plants growing on normal soil. At high metal concentration modified growth was observed in Imperata cylindrica, Lycopodium cernuum, Melastoma malabathricum, Mimosa pudica Linn, Nelumbo nucifera, Phragmites australis L., Pteris vittata L. and Salvinia molesta as compared to the low metal values as shown in (Table 4 and 5). Leaves of these plants were greenish yellow in colour, less glossy, more fragile and have crenulations of higher amplitudes along the leaf margins compared to the leaves of the similar species growing on soils without any metal enrichment. The roots of these plants that grow on high metals content soil were of smaller dimensions with relatively thinner barks, and on breaking or cutting fresh samples of them, plant sap oozed out from the wounds with a lesser vigour and in lesser quantities then from stems of those plants that were growing on normal soils. The ratio of leaf-length over leaf-base revealed that the leaves of above mentioned plants growing on soils with high metal 
values have relatively narrower leaf bases as shown in (Table 4). The fronds of these plants had shorter rachis, and smaller pinnules of lighter green in colour compared to similar species growing on normal soils. Their sporangia, which occur on the undersides of the pinnules, were lesser in number, whilst the rhizoids, which ramify in the subsoil, were thinner and had fewer adventitious roots compared with similar plants growing on normal soils. The leaf length to leaf base ratio is also shown in (Table 4 and 5).

High concentrations of these metals are responsible for the deformed characteristics in these plants. Some plants accumulated heavy metals in their tissues do not show any noticeable morphological changes in the leaves, twigs and in the roots because the level of concentration of heavy metal was not beyond the critical level for that plant or that the deformations only expressed in flower buds and fruits. The normal development of organs of plants in a way is depressed by the high concentrations of metals in their tissues. However the morphological modifications are not necessarily resulted from high levels of concentrations of copper, zinc, arsenic and tin in the plants but also arose from other elements that were not studied. Relatively low concentrations or the absence of certain essential elements such as calcium, magnesium, potassium and many others may also affect the metabolic activities. In addition, the abnormal growth of plants also may be due to diseases caused by bacteria and viruses and to physiological and genetic

Table 4: High Metal Value, plant leaf morphologies and type of amino acids not detected

\begin{tabular}{|c|c|c|c|c|c|c|}
\hline Site & Plants & Leaf Shape & $\begin{array}{l}\text { Max. leaf } \\
\text { length }(\mathrm{cm})\end{array}$ & $\begin{array}{l}\text { Maxl-base } \\
(\mathrm{cm})\end{array}$ & $\begin{array}{l}\text { Leaf-length: } \\
\text { Leaf-base }\end{array}$ & $\begin{array}{r}\text { Amino acids } \\
\text { not detected }\end{array}$ \\
\hline$\overline{\mathrm{S} 5}$ & Cyperus rotundus $L$. & Flanged V shaped & 19.0 & 1.0 & 19.00 & serine, glycine \\
\hline S6 & Imperata cylindrica L. Beauv. & Leaf blades flat or rolled & 77.0 & 1.0 & 77.04 & aspartic acid \\
\hline S4 & Lycopodium cernuum & Thin needle like & 1.8 & 0.2 & 9.00 & $\begin{array}{l}\text { glutamic acid, aspartic acid, } \\
\text { arginine }\end{array}$ \\
\hline S4 & Melastoma malabathricum L. & $\begin{array}{l}\text { leaf blade ovate, elliptic, } \\
\text { lanceolate }\end{array}$ & 5.8 & 2.4 & 2.41 & $\begin{array}{l}\text { glutamic acid, aspartic acid, aniline, } \\
\text { serine,arginine, glycine }\end{array}$ \\
\hline S6 & Mimosa pudica Linn. ${ }^{a}$ & Bipinnate & $15 .^{b}$ & $7.1^{\mathrm{b}}$ & 2.14 & glycine,serine \\
\hline S7 & Nelumbo Nucifera & Orbiculate & 21.3 & 21.2 & 1.004 & aspartic acid \\
\hline S5 & Phragmites australis $L$. & Leaf blades, broad, flat & 54.9 & 5.7 & 9.63 & $\begin{array}{l}\text { glutamic acid, aspartic acid, } \\
\text { arginine, aniline }\end{array}$ \\
\hline S4 & Pteris vittata $L$. & Bipinnate & $6.6^{\mathrm{d}}$ & $2.1^{\mathrm{d}}$ & 3.14 & aspartic acid,arganine \\
\hline S7 & Salvinia Molesta & 3 Whorls at each leaf node & 11.0 & 5.8 & 1.89 & $\begin{array}{l}\text { glutamic acid, aspartic acid, serine, } \\
\text { arginine }\end{array}$ \\
\hline
\end{tabular}

Using paper chromatography amino acids such as aniline, arginine, aspartic acid, glutamic acid, glycine and serine were detected in leaves of rest of the plants, cystine was only detected in the leaves of Vitis trifolia Linn

Table 5: Low Metal Value, plant morphologies and type of amino acids not detected

\begin{tabular}{|c|c|c|c|c|c|c|}
\hline Site & Plants & Leaf Shape & $\begin{array}{l}\text { Max. leaf- } \\
\text { length }(\mathrm{cm})\end{array}$ & $\begin{array}{l}\text { Max. leaf- } \\
\text { base }(\mathrm{cm})\end{array}$ & $\begin{array}{c}\text { Leaf-length: } \\
\text { leaf-base }\end{array}$ & $\begin{array}{l}\text { Amino acids } \\
\text { not detected }\end{array}$ \\
\hline$\overline{\mathrm{S} 5}$ & Cyperus rotundus $L$. & Flanged V shaped & 23.0 & 1.2 & 19.16 & e \\
\hline S6 & Imperata cylindrica & Leaf blades flat or rolled & 80.0 & 1.2 & 66.66 & aspartic acid \\
\hline S5 & Lycopodium cernuum & Thin needle like & 2.0 & 0.4 & 5.00 & arginine \\
\hline S4 & Melastoma malabathricum L. & $\begin{array}{l}\text { Leaf blade ovate, } \\
\text { Elliptic,lanceolate, }\end{array}$ & 6.2 & 2.9 & 2.13 & serine,arginine, \\
\hline S4 & Mimosa pudica Linn ${ }^{a}$. & Bipinnate & $15.8^{\mathrm{b}}$ & $7.4^{\mathrm{b}}$ & 2.13 & glycine \\
\hline S7 & Nelumbo Nucifera & Orbiculate & 21.8 & 21.6 & 1.009 & $\begin{array}{l}\text { aspartic acid, } \\
\text { analine }\end{array}$ \\
\hline S6 & Phragmites australis $L$. & Leaf blades, broad, flat & 56 & 6 & 9.33 & arginine, aniline \\
\hline S5 & Pteris vittata $L$. & Bipinnate & $6.8^{\mathrm{d}}$ & $2.1^{\mathrm{d}}$ & 3.23 & aspartric acid \\
\hline S7 & Salvinia Molesta & 3 Whorls at each leaf node & 13 & 6 & 2.16 & e \\
\hline
\end{tabular}

Leaves bipinnately compound, pinnate 2-4, digitately arranged with 10-20 pairs of leaflets, rachis clothed with ascending bristles ${ }^{\mathrm{b}}$ complete bipinnate leaf ${ }^{\mathrm{c}}$ Trilobed leaf ${ }^{\mathrm{d}}$ one side pin ${ }^{\mathrm{e}}$ not found any missing amino acid 
influences (Prasad and Strzalka, 2002). Observation of the modified morphological characteristics of the plant and the value of heavy metals in them suggest that plants with high concentration of heavy metals usually show growth abnormalities.

\section{CONCLUSION}

Soil analysis of the studied area show that mine tailing has the greatest probability of metals being leached because of the high heavy metal concentrations, low $\mathrm{pH}$ and low capacity of the soil to retain water and metals (low cation exchange capacity, percentage of sand higher than $50 \%$ and absence of structure). These conditions were likely to result in soluble metals that can leach into receiving waters. Metals transport in surface waters and leaching through the soil profile may result in the contamination of consumable water through mining catchment as it flows into the native river. Meanwhile some plant species can tolerate the adverse environmental conditions and have colonized the tailings. The different $\mathrm{pHs}$ of the tailings affects metal solubility and the establishment of different kind of plant species in each one. These species, despite growing in such polluted soil, do not accumulate high metal concentrations in their shoots. This is an effective and cheap option to stabilize tailing areas and also decrease erosion effects. On the neutral $\mathrm{pH}$ tailings, where plants encounter more favourable growing conditions, organic amendments may improve the water retention and soil structure. On the acidic tailings, the growth of identified dominant plant species can help to reduce the metal contaminants up to large extent. There is about 113,700 hectors of tin tailings throughout the Peninsular Malaysia. Identification of new plant specie as a potential tin hyperaccumulator is a major break through but still needs more exploration to make the specie feasible for growth in the tin tailings areas. In addition the plants behave in various ways towards the accumulation of metals in their tissues. Some plants show no restriction in the uptake of metals from soil over wide concentration ranges whilst others do so. The concentration of one metal that restricts the uptake of other metal in question from the soil by the plant varies from specie to specie. The accumulation of metals in plants affects the normal processes of plant metabolism. The study shows that there is a relationship between high metal value in plants and their modified suppressed growths together with the absence of certain amino acids in these plants. However further work needs to be done in order to reveal a better understanding between the effects of metal concentration in plants on their growths and on their synthesis of amino acids.

\section{ACKNOWLEDGEMENTS}

The work reported in this paper was carried out in Analytical Laboratory, Department of Chemistry, University of Malaya, Kuala Lumpur, Malaysia through UM Research Grant vide no. PS355/2009C. Thanks also to the Ministry of Higher Education Malaysia (MOHE) for their financial support.

\section{REFERENCES}

Alvarez, E.; Fernández Marcos, M. L.; Vaamonde, C.; Fernández-Sanjurjo, M. J., (2003). Heavy metals in the dump of an abandoned mine in Galicia (NWSpain) and in the spontaneously occurring vegetation. Sci. Total Environ., 313 (1-3), 185-197 (13 pages).

Ashraf, M. A.; Maah, M. J.; Yusoff, I., (2010). Study of water quality and heavy metals in soil and water of ex-mining area Bestari Jaya, Peninsular Malaysia, Int. J. Basic. Appl. Sci., 10 (3), 7-27 (21 pages).

Atafar, Z.; Mesdaghinia, A.; Nouri, J.; Homaee, M.; Yunesian, M.; Yunesian, M.; Ahmadimoghaddam, M.; Mahvi, A. H., (2010). Effect of fertilizer application on soil heavy metal concentration. Environ. Monitor. Assess. 160 (1-4), 8389 ( 7 pages).

Ayari, F.; Hamdi, H.; Jedidi, N.; Gharbi, N.; Kossai, R., (2010). Heavy metal distribution in soil and plant in municipal solid waste compost amended plots. Int. J. Environ. Sci. Tech., 7 (3), 465-472 (8 pages).

Baker, A. J. M., (1981). Accumulators and excluders strategies in the response of plants to heavy metals. J. plant nutr. 3 (1-4), 643-654(12 pages).

Baker, A. J. M.; Brooks, R. R., (1989). Terrestrial higher plants which hyperaccumulate metallic elements. A review of their distribution, ecology and phytochemistry. Biorecovery, 1, 81-126 (36 pages).

Baker, A. J. M.; Reeves, R. D.; Hajar, A. S. M., (1994). Heavy metal accumulation and tolerance in British populations of the metallophyte Thlaspi cearulescens J. and C. Presl. (Brasicaceae)., New Phytol. 127 (1), 61-68 (8 pages).

Baker, A. J. M., (1995). Metal hyperaccumulation by plants: our present knowledge of the ecophysiological phenomenon. In: Will Plants Have a Role in Bioremediation? $14^{\text {th }}$ Annual Symp. Current Topics in Plant Biochemistry, Physiology and Molecular Biology, 19-22 April, 7-8, Columbia, MO.

Batty, L. C.; Baker, A. J. M.; Wheeler, B. D.; Curtis, C. D., (2000). The Effect of $\mathrm{pH}$ and plaque on the uptake of $\mathrm{Cu}$ and $\mathrm{Mn}$ in Phragmites australis(Cav.) Trin ex. Steudel. Ann. Bot., 86 (3), 647-653 (7 pages). 
Baudo, R.; Canzian, E.; Galanti, G.; Guilizzoni, P.; Rapetti, G., (1985). Relationships between heavy metals and aquatic organisms in Lake Mezzola hydrographc system (Northern Italy) Hydrochemestry. Mem. Ist. Ital. Idrobiol., 43, 161180 (19 pages).

Bischof, C., (1996 ). Effects of heavy metal stress on free amino acids in the haemolymph and proteins in haemolymph and total body tissue of Lymantria dispar larvae parasitized by Glyptapanteles liparidis., Entomol. Experimental. et Appl., 79 ( 1) 61-68 (8 pages).

Boularbah, A.; Bitton, G.; Morel, J. L.; Schwartz, C., (2000). Assessment of metal accumulation in plants using MetPAD, a toxicity test specific for metal toicity. Environ. Toxicol., 15 (5), 449-455 (7 pages).

Boularbah, A.; Schwartz, C.; Bitton, G.; Morel, J. L., (2006). Heavy metal contamination from mining sites in south Morocco: 1 . Use of a biotest to assess metal toxicity of tailings and soils. Chemosphere, 63 (5), 802-810 (9 pages).

Bradshaw, A. D.; Humphreys, M. O.; Johnson, M. S., (1978). The value of heavy metal tolerance in the revegation of metalliferous mine wastes, in: Goodman, G. T., Chadwick, M. J. (Eds.), Environmental management of mineral wastes. Sitjhoff and Noordhoff, The Netherlands, 311-314(4 pages).

Brooks, R. R., (2000). Plants that Hyperaccumulate Heavy Metals. CAB International, Cambridge, UK, 380-385 (6 pages).

Brotheridge, R. M.; Newton, K. E.; Taggart, M. A.; McCormick, P. H.; Evans S. W., (1998). Nickel, cobalt, zinc and copper levels in brown trout (Salmo trutta) from the river Otra, Southern Norway., Analyst, 123 (1), 69-72 (4 pages).

Camel, V., (2000). Microwave-assisted solvent extraction of environmental samples. TrAC Trends in Anal. Chem., 19 (4), 229-248 (20 pages).

Carpena-Ruiz, R.; Sopeña, A.; Ramon, A. M., (1989). Extraction of free amino acids from tomato leaves. Plant Soil., 119 (2), 251-254 (4 pages).

Charles, C. W.; Glenn, S. R., (1953). The composition of plant fractions extracted with $80 \%$ alcohol. Plant Physiol., 28 (3), 535-538 (4 pages).

Conesa, H. M.; Faz, A.; Arnaldos, R., (2006). Heavy metal accumulation and tolerance in plants from mine tailings of the semiarid Cartagena-La Union mining district. Sci. Total Environ., 366 (1), 1-11 (11 pages).

Deng, H.; Ye, Z. H.; Wong, M. H., (2004). Accumulation of lead, zinc, copper and cadmium by 12 wetland plant species thriving in metal-contaminated sites in China. Environ. Pollut., 132 (1), 29-40 (12 pages).

Dowdy, D. L.; McKone, T. E., (1997). Predicting plant uptake of organic chemicals from soil or air using octanol/water and octanol/air partitioning ratios and a molecular connectivity index. Environ. Toxicol. Chem., 16 (12), 2448-2456 (8 pages).

Dudka, S.; Adriano, D. C., (1997). Environmental impacts of metal ore mining and processing: A review. J. Environ. Qual., 26 (3), 590-602 (13 pages).

Fayiga, A. O.; Ma, L. Q.; Cao, X.; Rathinasabapathi, B., (2004). Effects of heavy metals on growth and arsenic accumulation in the arsenic hyperaccumulator Pteris vittata L. Environ. Poll., 132 (2), 289-296 (8 pages).

Freitas, H.; Prasad, M. N. V.; Pratas, J., (2004). Plant community tolerance and trace elements growing on the degraded soils of Sao Domingos mine in the south east of Portugal: Environmental implications. Environ. Int., 30 (1), 65-72(8 pages).

Gardea-Torresdey, J. L.; Peralta-Videa, J. R.; de la Rosa, G.; Parsons, J. G., (2005). Phytoremediation of heavy metals and study of the metal coordination by X-ray absorption spectroscopy. Coordin. Chem. Rev., 249 (17-18), 17971810 (14 pages).

Gee, G. W.; Bauder, J. W., (1986). Particle soil analysis. in: Klute, A. (Ed.), Methods for soil analysis. Part 1: Physical and mineralogical methods. Soil Science Society of America. American Society of Agronomy, Madison, Wisconsin, USA., 383- 411 (39 pages).

Gibbs, M. I., (1951). The position of C14 in sunflower leaf metabolites after exposure of leaves to short period photosynthesis and darkness in an atmosphere of C1402., Plant Physiol. 26 (3), 549-556 (8 pages).

Goyal, P.; Sharma, P.; Srivastava, S.; Srivastava, M. M., (2008). Saraca indica leaf powder for decontamination of $\mathrm{Pb}$ : Removal, recovery, adsorbent characterization and equilibrium modeling. Int. J. Environ. Sci. Tech., 5 (1), 27-34 (8 pages).

Griepink, B.; Muntau, H., (1988). The Certification of the Contents (Mass Fractions) of As, B, Cd, Cu, Hg, Mn, Mo, $\mathrm{Ni}, \mathrm{Pb}, \mathrm{Sb}$, Se and $\mathrm{Zn}$ in Rye Grass-CRM 281. Office for Official Publications of the European Communities, Luxembourg.

Hall, W. S.; Pulliam, G. W., (1995), An assessment of metals in an estuarine wetlands ecosystem. Arch. Environ. Contam. Toxicol., 29 (2), 164-173 (8 pages).

Henriques, F. S.; Fernandes, J. C., (1991). Metal uptake and distribution in rush (Juncus conglomeratus L.) plants growing in pyrites mine tailings at Lousal, Portugal. Sci. Total Environ., 102, 253-260 (8 pages).

Johansen, P.; Asmund, G., (2001). Pollution from mining in Greenland-a review, in: Olsen, H. K., Lorentzen, L., Rendal, O. (Eds.), Mining in the arctic. The Netherlands: A. A. Balkema Publishers, 29-36 (8 pages).

Johnson, D. B.; Hallberg, K. B., (2005). Acid mine drainage remediation options: A Rev., Sci. Total Environ. 338 (12), 3-14 (12 pages).

Keller, B. E. M.; Lajtha, K.; Cristofor, S., (1998). Trace metal concentrations in the sediments and plants of the Danube Delta, Romania., Wetlands. 18, 42-50 (9 pages).

Ling, T.; Guanghua, Z.; Jun, R., (2009). Effects of chromium on seed germination, root elongation and coleoptile growth in six pulses. Int. J. Environ. Sci. Tech., 6 (4), 571-578 (8 pages).

Malakootian, M.; Nouri, J.; Hossaini, H., (2009). Removal of heavy metals from paint industry's wastewater using Leca as an available adsorbent. Int. J. Environ. Sci. Tech., 6 (2) 183-190 (8 pages)

Mateo, R.; Taggart, M.; Green, A. J.; Cristòfol, C.; Ramis, A.; Lefranc, H.; Figuerola, J.; Meharg, A. A., (2006). Altered porphyrin excretion and histopathology of greylag geese (Anser anser) exposed to soil contaminated with lead and 
arsenic in the Guadalquivir Marshes, SW Spain. Environ. Toxicol. Chem., 25 (1), 203-212 (10 pages).

Mattina, M. I.; Lannucci-Berger, W.; Musante, C.; White, J. C., (2003). Concurrent plant uptake of heavy metals and persistent organic pollutants from soil. Environ. Pollut., 124 (3), 375-378 (4 pages).

McNeill, J., (2006). International Code of Botanical Nomenclature (VIENNA CODE), adopted by the $17^{\text {th }}$ International Botanical Congress Vienna, Austria.

McGrath, S. W.; Zhao, F. J.; Lombi, E., (2001). Plant and rhizosphere processes involved in phtoremediation of metalcontaminated soils. Plant and Soil, 232 (1-2), 207-214 (8 pages).

Mickel, J. T., (1992). Pteridophytes, in: McVaugh, R. (Ed.), Flora Novo-Galiciana. A descriptive account of the vascular plants of Western Mexico, vol. 17. University of Michigan Herbarium, Ann Arbor, 120-431 (12 pages).

Min, Y.; Boquing, T.; Meizhen, T.; Aoyama, I., (2007). Accumulation and uptake of manganese in a hyperaccumulator Phytolacca americana. Miner. Eng., 20 (2), 188-190 (3 pages).

Mizell, M.; Sidney, B.; Simpson, Jr., (1961), Paper chromatographic separation of amino acids: A solvent to replace phenol. J. Chromatograph. A (5), 157-160 (4 pages).

Monni, S.; Uhlig, C.; Hansen, E.; Magel, E., (2001). Ecophysiological responses of Empertrum nigrum to heavy metal pollution. Environ. Poll., 112 (2), 121-129 (9 pages).

Moran, R. C.; Riba, R., (1995). Psiolotaceae and Salviniaceae. Flora Mesoamericana, vol. 1. Universidad Nacional Autónoma de México, México, DF.

Morel, J. L.; Bitton, G.; Schwartz, C.; Schiavon, M., ( 1997). Bioremediation of soils and waters contaminated with micropollutants: With role of plants, in: Zelikoff, J. J., Lynch, J. M., Sheppers, J., Eds., Ecotoxicology: Responses, Biomarkers and risk assessment OECD, 1-38 (38 pages).

Nelson, D. W.; Sommers, L. E., (1982). Total carbon, organic carbon and organic matter, in: Page, L. (Ed.), Methods of soil analysis. Part 2. Agronomy 9. American Society of Agronomy, Madison, WI. 539-279 (41 pages).

Norland, M. R.; Veith, D. L., (1995). Revegetation of coarse taconite iron ore tailing using municipal waste compost. J. Hazard. Mater., 41 (2-3), 123-134 (12 pages) .

Nouri, J., (1980). Heavy metals in sewage sludge, soils amended with sludge and their uptake by crop plants. Ph.D. thesis, University of London, London, UK.

Nouri, J.; Karbassi, A. R.; Mirkia, S., (2008). Environmental management of coastal regions in the Caspian Sea. Int. J. Environ. Sci. Tech., 5 (1), 43-52 (10 pages).

Nouri, J.; Khorasani, N.; Lorestani, B.;Yousefi, N.; Hassani, A. H.; Karami, M., (2009). Accumulation of heavy metals in soil and uptake by plant species with phytoremediation potential. Environ. Earth Sci., 59 (2), 315-323 (9 pages).

Nouri, J.; Lorestani, B.; Yousefi, N.; Khorasani, N.; Hasani, A. H.; Seif, S.; Cheraghi, M., (2011). Phytoremediation potential of native plants grown in the vicinity of Ahangaran lead-zinc mine Hamedan, Iran. Environ. Earth Sci., 62 (3), 639-644 (6 pages).

Nwuche, C. O.; Ugoji, E. O., (2008). Effects of heavy metal pollution on the soil microbial activity. Int. J. Environ. Sci. Tech., 5 (3), 409-414 (6 pages).
Prasad, M. N. V.; Strzalka, K., (2002). Physiology and Biochemistry of Metal Toxicity and Tolerance in Plants. $1^{\text {st }}$ Ed., Kluwer Academic Publishers, Dordrecht, 330-432 (103 pages).

Peverly, J. H.; Surface, J. M.; Wang, T., (1995). Growth and trace metal absorption by Phragmites australis in wetlands constructed for landfill leachate treatment. Ecol. Eng., 5 (1), 21-35 (15 pages).

Reeves, R. D.; Baker, A. J. M., (2000). Metal-accumulating plants, in: Raskin, I., Ensley, B. D. (Eds.), Phytoremediation of toxic metals: using plants to clean up the environment. John Wiley and Sons Inc., New York, USA, 193-230 (38 pages).

Rout, G. R.; Das, P., (2003). Effect of metal toxicity on plant growth and metabolism: I. Zinc., Agron., 23 (1), 3-11 (9 pages).

Rowell, D. J., (1994). Soil Science. Methods and Applications, Longman, Essex, England, 149-150 (12 pages).

Santillan, L. F. J.; Constantino, C. A. L.; Rodriguez, G. A. V.; Ubilla, N. M. C.; Hernandez, R. I. B., (2010). Manganese accumulation in plants of the mining zone of Hidalgo, Mexico. Biores. Tech., 101 (15), 5836-5841 (6 pages).

Scholes, L. N. L.; Shutes, R. B. E.; Revitt, D. M.; Purchase, D.; Forshaw, M., (1999). The removal of urban pollutants by wetlands during wet weather. Wat Sc. Tech., 40 (3), 333340 ( 8 pages).

Singh, A. N.; Zeng, D. H.; Chen, F. S., (2005). Heavy metals concentration in re-developing soil of mine spoil under plantation of certain native woody species in dry tropical environment, India. J. Environ. Sci., 17 (1), 168-174 (7 pages).

SISS, (1985). Metodi normalizzati per l'analisi del suolo. Societa“ Italiana per la Scienza del Suolo, Edagricole, Bologna.

Shah, B. A.; Shah, A. V.; Singh, R. R., (2009). Sorption isotherms and kinetics of chromium uptake from wastewater using natural sorbent material. Int. J. Environ. Sci. Tech., 6 (1), 77-90 (14 pages).

Sheldon, A. R.; Menzies, N. W., (2005). The Effect of copper toxicity on the growth and root morphology of Rhodes Grass (Chloris gayana Knuth.) in resin buffered solution culture. Plant and Soil, 278 (1-2), 341-349 (9 pages).

Sun, Q.; Ye, Z. H.; Wang, X. R.; Wong, M. H., (2005). Increase of glutathione in mine population of Sedum alfredii: A Zn hyperaccumulator and $\mathrm{Pb}$ accumulator. Phytochem., 66 (21), 2549-2556 (8 pages).

Thomas, G. W., (1996). Soil pH and soil acidity, in: Sparks, D. L. (Ed.), Methods for soil analysis. Part 3: Chemical methods. Soil Science Society of America. American Society of Agronomy, Madison, Wisconsin. USA, 475-490 (16 pages).

Tordoff, G. M.; Baker, A. J. M.; Willis, A. J., (2000). Current approaches to the revegetation and reclamation of metalliferous mine wastes. Chemosphere, 41 (1-2), 219228 (10 pages).

Wilson, B.; Pyatt, F. B., (2007). Heavy metal dispersion, persistance, and bioccumulation around an ancient copper mine situated in Anglesey, UK. Ecotoxicol. Environ. Safety, 66 (2), 224-231 (8 pages). 
Wong, J. W. C.; Ip, C. M.; Wong, M. H., (1998). Acid-forming capacity of lead-zinc mine tailings and its implications for mine rehabilitation. Environ. Geochem. Health, 20 (3), 149-155 (7 pages).

Wong, M. H., (2003). Ecological restoration of mine degraded soils, with emphasis on metal contaminated soils. Chemosphere, 50 (6), 775-780 (6 pages).

Yanqun, Z.; Yuan, L.; Schvartz, C.; Langlade, L.; Fan, L., (2004). Accumulation of $\mathrm{Pb}, \mathrm{Cd}, \mathrm{Cu}$ and $\mathrm{Zn}$ in plants and hyperaccumulator choice in Lanping lead-zinc mine area, China. Environ. Int., 30 (4), 567-576 (10 pages).

Ye, Z. H.; Baker, A. J. M.; Wong, M. H.; Willis, A. J., (1997). Zinc, lead and cadmium tolerance, uptake and accumulationby the common reed, Phragmites australis (Cav.) trin. ex steudel. Ann. Bot., 80 (3), 363-370 (8 pages).

Younger, P. L., (2001). Mine water pollution in Scotland: Nature, extent and preventative strategies. Sci. Total Environ., 265 (1-3), 309-326 (18 pages).

Zhang, W.; Cai, Y.; Tu, C.; Ma, L. Q., (2002). Arsenic speciation and distribution in an arsenic hyperaccumulating plant. Sci. Total Environ., 300 (1-3), 167-177 (11 pages).

Zvinowanda, C. M.; Okonkwo, J. O; Shabalala, P. N.; Agyei, N. M., (2009). A novel adsorbent for heavy metal remediation in aqueous environments. Int. J. Environ. Sci. Tech., 6 (3) 425-434 (10 pages).

\section{AUTHOR (S) BIOSKETCHES}

Ashraf, M. A., Research Scholar, Department of Chemistry, University of Malaya, Kuala Lumpur 50603, Malaysia.

E-mail: chemaqeel@gmail.com

Maah, M. J., Professor, Department of Chemistry, University of Malaya, Kuala Lumpur 50603, Malaysia. E-mail: jamilmaah@gmail.com

Yusoff, I., Associate Professor, Department of Geology, University of Malaya, Kuala Lumpur 50603, Malaysia.

E-mail: ismaily70@um.edu.my

How to cite this article: (Harvard style)

Ashraf M. A.; Maah, M. J.,Yusoff, I., (2011). Heavy metals accumulation in plants growing on former tin mining catchment.Int. J.

Environ. Sci. Tech., 8 (2), 401-416. 